AL-AMWAL: JURNAL EKONOMI DAN PERBANKAN SYARI'AH (2021) Vol 13: 138-152 DOI: $10.24235 /$ amwal.v\%vi\%i.8551

Al-Amwal: Jurnal Ekonomi dan Perbankan Syariah ISSN: 2303-1573 e-ISSN: 2527-3876

Homepage: https://www.syekhnurjati.ac.id/jurnal/index.php/amwal email: jurnalalamwal@syekhnurjati.ac.id

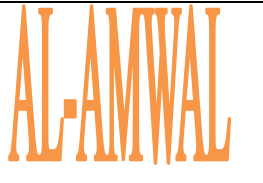

\title{
HUMAN DEVELOPMENT INDEX (HDI), GROSS REGIONAL DOMESTIC PRODUCT (GRDP) PER CAPITA AND INCOME DISTRIBUTION: AN ANALYSIS OF NATIONAL ZAKAT REVENUE
}

\author{
Najla \\ Universitas Indonesia \\ email: najlawildan95@gmail.com \\ Okta Yuripta Syafitri \\ Universitas Indonesia \\ email: oktayuripta@gmail.com \\ Nurul Huda \\ Universitas Yarsi \\ email: nurul.huda@yarsi.ac.id
}

\begin{abstract}
This study aims to look at the related factors that affect national zakat receipts, namely the Human Development Index, GDP per capita, and income distribution. This type of research is descriptive quantitative using cross-sectional design and the sample in this study is 34 provinces in Indonesia. The data used is secondary data obtained from the Central Statistics Agency (BPS) for HDI data, per capita GRDP, GINI Ratio Index, and BAZNAS for data on zakat acceptance in 2018. The data were then analyzed using multiple linear regression analysis methods. The results obtained are the variable Gini ratio (income distribution) has a significant positive effect with a percentage of $313.2 \%$, while the other two variables have an indirect influence.
\end{abstract}

Keywords: Zakat, BAZNAS, HDI, GRDP per capita, Income Distribution 


\begin{abstract}
Abstrak
Tujuan penelitian ini adalah untuk melihat faktor- faktor terkait yang mempengaruhi penerimaan zakat nasional; IPM, PDRB per kapita, dan Distribusi Pendapatan. Jenis penelitian ini adalah kuantitatif deskriptif dengan menggunakan rancangan cross sectional, sampel dalam penelitian ini adalah 34 provinsi di Indonesia. Jenis data yang digunakan adalah data sekunder yang didapatkan dari Badan Pusat Statistik (BPS) untuk data IPM, PDRB per kapita, Indeks Gini Ratio. dan BAZNAS untuk data penerimaan zakat pada tahun 2018, data kemudian dianalisis dengan metode analisis regresi linier berganda. Hasil yang didapatkan adalah variabel gini ratio (distribusi pendapatan) berpengaruh secara positif signifikan dengan hasil persentase $313,2 \%$, sedangkan dua variabel lainnya berpengaruh secara tidak lansung. Secara keseluruhan seluruh variabel independen berpengaruh sebanyak $27,8 \%$ terhadap variabel dependen.
\end{abstract}

\title{
Kata Kunci: Zakat, BAZNAS, IPM, PDRB per kapita, Distribusi Pendapatan
}

\section{INTRODUCTION}

Advancing the general welfare and the intellectual life of the nation are the national ideals listed in the 1945 Constitution, which becomes the reference for every leader, both at the state and the provincial and regional levels. The essence of this hope is contained in every work program compiled by the government, which is carried out in each term of office.

In reality, poverty is still the main problem faced by the Indonesian State to this day. Although, the Central Statistics Agency noted that there had been a decrease in the poverty rate by $9.22 \%$, equivalent to 24.79 million people. This figure is not too significant compared to the previous period, which only decreased by $0.19 \%$. The decline factor was predominantly affected by the NonCash Food Assistance (BPNT) program, which was implemented by the government at the end of 2019 intensively. (Fauzia, 2020). This poverty phenomenon is becoming more and more worrying when compared to members of ASEAN countries. Vietnam's poverty rate for 2008 - 2010 reached when Vietnam's per capita income was only $42 \%$ of Indonesia's per capita income in 2018. (Saparini, 2020).

It is outlined in the UNDP report that Indonesia has joined the ranks of countries in the world with high human development, and the Asia-Pacific region has experienced the sharpest increase globally for human development. However, multidimensional poverty and inequality in Indonesia are scourges that have not been resolving. (UNDP, 2019).

Given the fact above, an alternative instrument is essential to reduce poverty levels. One such instrument is the zakah. Human development and its components such as health/life expectancy, education, and living standard/ income have strong correlation with the theory of welfare, which is also known as maqashid shari'a in Islamic perception. Zakah interprets as one of the most prominent concepts is present as a way to achieve that goal, not only from an economic perspective, but also various other indicators (I.K.Balyanda AKMAL, 
2020). It is in line with what was narrated by Rasulullah SAW in a Hadith: "Indeed, Allah SWT has obliged Muslim journalists to have an obligation of zakat which can alleviate poverty. A poor person cannot suffer from hunger or lack of clothing, except because of the naughtiness that exists in Muslim journalists. Remember, Allah SWT will make careful calculations and hold them accountable and will further torture them with grievous torment". (at-Thabrani, 2012).

In the last few years, potency the development and utilization of zakat in Indonesia tend to increase. It can be seen from the amount of zakat collection by Baznas, which always increases every year. Bambang Sudibyo, the Chairperson of the National Amil Zakat Agency said that the potential for zakat in Indonesia could reach IDR 232 trillion if it paid by all Muslim communities in the country, which totaled 209 million people (Indonesia, 2019)

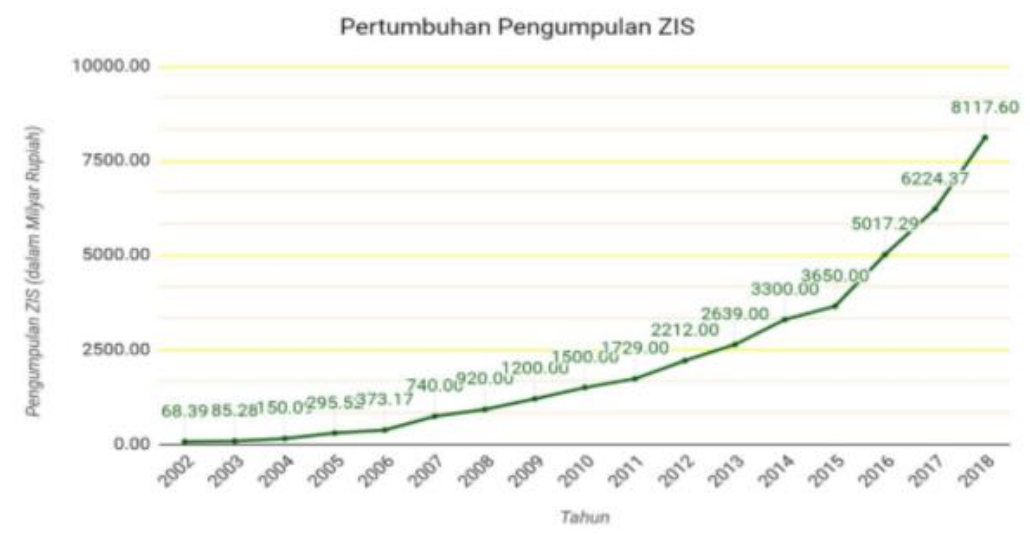

Source: National Zakat Statistics, 2018

Figure1. National Zakat Statistics

The preceding explanation conforms with the statement of President Joko Widodo at the Zakat Handover event at the State Palace that "Zakat is very important to drive good economic growth, alleviate poverty, improve people's welfare, and encourage Indonesia to become the center of the world's sharia economy " (Ashari, 2019). In addition, according to (Kasri, 2016) to maximize the potential of zakat, it is necessary to set zakat targets by related institutions in alleviating poverty.

Research on the impact of zakat and economic growth, HDI (Human Development Index), and Income Distribution has been conducted by many practitioners, academicians, with many variations in their findings. The research conducted by (Badruddin, 2019), studied the influence of zakat on economic growth and society welfare used the Human development Index, percentage of poor people and the GINI Index as variable. Another study by (Suprayitno, 2018) on the impact of zakat distribution on macroeconomic conducted in Malaysia finds that zakat has positive and significant relationship with economic growth, consumption and investment.

Several studies that have been conducted previously focused on the effect of zakat on macroeconomic variables using HDI, Gini Index, GRDP and others variables. To overview the overall picture in detail, the author wants to focus on examination the level of national zakat revenue with various related indicators in 
terms of the Human Development Index (HDI), Gross Regional Domestic Product (PDRB), and distribution patterns of public income at every province in Indonesia. The aim of this study is that conclusions can be drawn about the zakat acceptance index on a macro level so that the government and related agencies or institutions (BAZNAS) can have views on aspects that can increase national zakat revenue.

\section{LITERATURE REVIEW}

\section{Human Development Index (HDI)}

One of the parameters to measure the success rate of development is by looking at the Human Development Index (HDI) or Human Development Index (HDI), which based on three indicators; 1) life expectancy at birth, 2) adult literacy rate, and mean years of schooling, 3) purchasing power parity

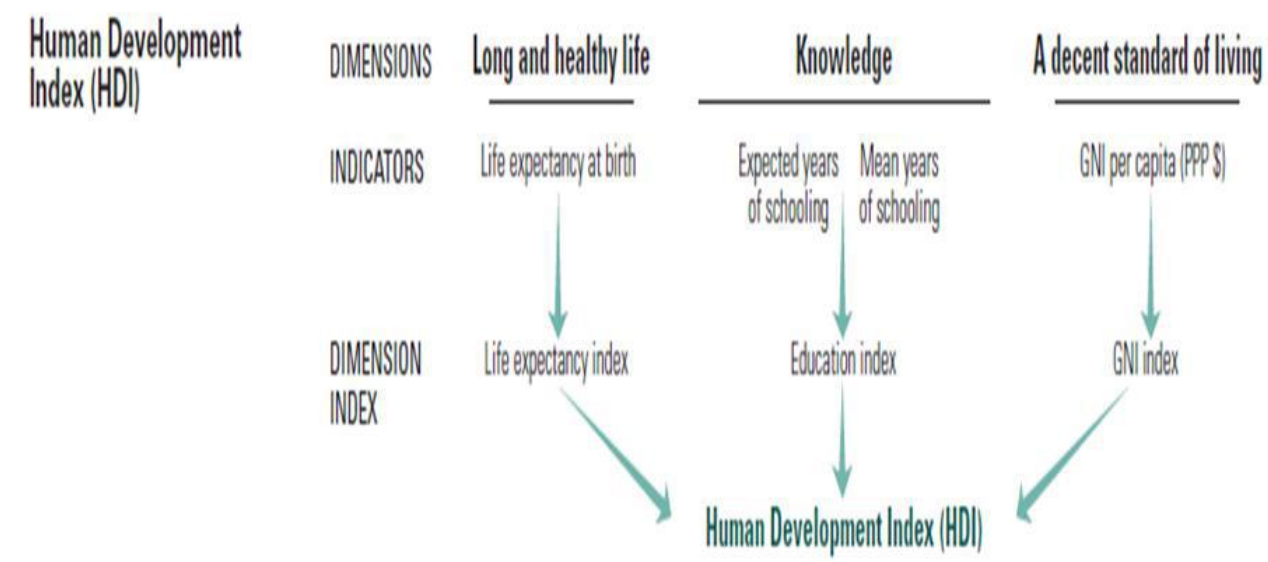

(Latuconsina, 2017).

Source: (Programme, 2019)

Figure2. Three Dimensions of the Human Development Index

Indonesia was ranked 111th out of 189 countries in achieving the HDI as reported by UNDP 2019 with an HDI of 70.7 percent, which is included in the country with the Medium Human Development Index category. A high HDI indicates the welfare and quality of human life; acts as an indicator to explain the extent of people's access to income, education, health (Juliarini, 2018).

\section{Gross Regional Domestic Product (GRDP) Per Capita}

The definition of economic growth, in general, is an increase in an economy; producing goods and services, the resulting economic change is quantitative (quantitative change) can be calculated using GRDP data; revenue, the final market value of goods and services produced during a certain period of the year (Umaruddin Usman, 2018). According to the Central Statistics Agency (BPS), GRDP is defined as the amount of added value generated by all business units in an area or the total value of the final goods and services produced by all economic units in the region (Himawan Yudistira Dama, 2016).

\section{Income Distribution}


The administration of government carried out by the government essentially focuses on three main functions, namely the distribution function, the stabilization function, and the allocation function. The distribution function and stabilization function, in general, are more effectively carried out by the Central Government. Sources of Regional Income in Provinces consist of Regional Original Income (PAD), Transfer Funds, Regional Loans, and so on from legitimate income. (Juliarini, 2018). According to (Dewi Azizah Meydiasari, 2017), income distribution itself is the difference in the number of income earnings by the community and results in a large gap between layers in society, so that welfare can only be felt by certain groups, to determine the pattern of the income distribution can be measured through the Gini Index or Gini Ratio. The Gini index has a value between 0 (perfect evenness) to 1 (perfect inequality).

\section{Zakat Potential}

According to (Clarashinta Canggih, 2017) regarding the receipt of zakat funds and their potential. It is known based on previous studies that the estimation of zakat potential terminated in three ways, namely; 1) Based on traditional fiqh, 2) based on calculations from Qardawi, namely income zakat is calculated as $2.5 \%$, then the net profit on fixed assets is calculated as $10 \%, 3$ ) modification of the Qardawi version, namely all zakat originating from fixed assets and income is calculated the same at $2.5 \%$. The conclusion of the study reveals that the potential for zakat in Indonesia ranges from 1 to 2 percent of GDP.

The absorption of zakat funds in an area clearly from the value of NZI which is composed of two dimensions, namely; macro dimension, including the value of APBN support for BAZNAS and database of zakat institutions. The micro dimension includes institutional indicators with the collection, management, distribution, and reporting variables. The second indicator is the impact of zakat including; Material and Spiritual Welfare (CIBEST Welfare Index), Education and Health (HDI Modification) as well as independent variables (Nasional, 2019).

\section{METHOD}

\section{Data Collection Technique}

This study uses a correlational design to determine the relationship of two or more variables with a cross-sectional study approach. The type of data used is secondary data obtained from the Central Bureau of Statistics in 2018. In this study the authors will use a sample of data from 34 provinces in Indonesia in 2018. . 
Operational definition of a variable

Table 1. Operational definition of a variable

\begin{tabular}{|c|c|c|}
\hline Variable & $\begin{array}{l}\text { Operational } \\
\text { Definition }\end{array}$ & Indicator \\
\hline $\begin{array}{l}\text { Human Development } \\
\text { Index (HDI) (X1) }\end{array}$ & $\begin{array}{l}\text { Combined } \\
\text { measure of } \\
\text { health, education } \\
\text { and income, } \\
\text { published by } \\
\text { United Nations } \\
\text { Development } \\
\text { (UNDP) } \\
\text { (Varlitya, 2017) }\end{array}$ & $\begin{array}{l}\text { 1. Life } \\
\text { expectancy at } \\
\text { birth } \\
\text { 2. Adult literacy } \\
\text { rates and } \\
\text { average } \\
\text { length of } \\
\text { schooling } \\
\text { 3. Purchasing } \\
\text { power. }\end{array}$ \\
\hline $\begin{array}{l}\text { Economic Growth } \\
\text { (GRDP) (X2) }\end{array}$ & $\begin{array}{l}\text { The final value } \\
\text { of goods and } \\
\text { services } \\
\text { produced by the } \\
\text { economic sector / } \\
\text { business unit at a } \\
\text { certain time, } \\
\text { usually for a } \\
\text { year. Per capita } \\
\text { income is the } \\
\text { average income } \\
\text { of each resident } \\
\text { in a year. }\end{array}$ & $\begin{array}{l}\text { Real per capita } \\
\text { income. Per capita } \\
\text { income can be } \\
\text { calculated by } \\
\text { dividing national } \\
\text { income by the } \\
\text { number of residents. }\end{array}$ \\
\hline Income Distribution (X3) & $\begin{array}{l}\text { An even picture } \\
\text { of whether or not } \\
\text { the development } \\
\text { of a country } \\
\text { among the } \\
\text { population is } \\
\text { divided into two } \\
\text { things, namely; } \\
\text { first, increasing } \\
\text { the standard of } \\
\text { living of people } \\
\text { who are below } \\
\text { the poverty line, } \\
\text { second, equal } \\
\text { distribution of } \\
\text { income as a }\end{array}$ & $\begin{array}{l}\text { The Gini index has a } \\
\text { value between } 0 \\
\text { (perfect evenness) to } \\
1 \text { (perfect inequality). }\end{array}$ \\
\hline
\end{tabular}




\begin{tabular}{|c|c|c|}
\hline & $\begin{array}{l}\text { whole, narrowing } \\
\text { the gap (Sobirin, } \\
\text { 2016) }\end{array}$ & \\
\hline Zakat (Y) & $\begin{array}{l}\text { Micro National } \\
\text { Zakat Index } \\
\text { includes several } \\
\text { variables } \\
\text { including; } \\
\text { collection, } \\
\text { management, } \\
\text { distribution, } \\
\text { reporting, } \\
\text { CIBEST Welfare } \\
\text { Index, IPM } \\
\text { modification, and } \\
\text { Independence. }\end{array}$ & $\begin{array}{l}\text { 1. Institutional } \\
\text { 2. Impact of Zakat }\end{array}$ \\
\hline
\end{tabular}

Source: Primary data processed, 2020

\section{Method of Analysis}

The analysis method used in this research is quantitative data analysis with inferential and descriptive types; with an effort to draw conclusions based on the statistical analysis by looking for the relationship or influence between two or more variables; independent and dependent (Muhson) using the results of the multiple regression SPSS statistical test.

The regression model used in this study will use multiple linear regression models, to analyze the relationship between independent and dependent variables.

$$
\mathrm{Y}=\mathbf{a}+\boldsymbol{\beta}_{1} \mathbf{X} 1+\beta_{2} \mathrm{X} 2+\beta_{3} \mathrm{X} 3+\mathrm{e}
$$

Information:

Y : Impact of Zakat (Micro)

a : Constanta

$\beta_{1} \quad$ : Regression coefficient

$\beta_{2} \quad$ : Regression coefficient

$\beta_{3} \quad$ : Regression coefficient

$\mathrm{X} 1$ : HDI

X2 : GRDP

X3 : Gini Ratio

e : Disturbance variable 


\section{RESULTS AND DISCUSSION \\ Regression Equations}

$$
Y=3.254+6,946 X 1+-0.005 X 2+0.904 \times 3+e
$$

Table 2.Coefficient

\begin{tabular}{llll}
\hline Model & \multicolumn{2}{c}{ Coefficient } & \\
\hline & & Unstandardized & Sig \\
& & Coefficients & \\
\hline \multirow{2}{*}{1} & (Constants) & -193 & 0.635 \\
& X1 & 0.004 & 0.466 \\
& X2 & -0.012 & 0.231 \\
& X3 & 1796 & 0.004 \\
\hline
\end{tabular}

Source: Primary data processed, 2020

Based on the above equation, it can be seen that:

a. A constant value of -193 indicates that if the HDI, GRDP, and Gini Ratio variables are zero or constant, then the value of the Zakat variable is -193 points.

b. The regression coefficient of the HDI variable (X1) is -0.004 . This means that the average HDI has the opposite effect with Zakat. So if the average HDI has increased, then Zakat will decrease and if the average HDI decreases by 1 percent, Zakat will increase by -0.004 points.

c. The regression coefficient of the GRDP variable (X2) is -0.012. It means that the average GRDP has the opposite effect on Zakat. So that if the average GRDP rate increases, Zakat will decrease, and if the average GRDP rate decreases by 1 percent, zakat will increase by -0.0125 points.

d. The regression coefficient of the income distribution (X3) variable is 1.796. It means that the average Gini Ratio has the same effect as Zakat. So that if the average Gini Ratio increases, Zakat will increase, and if the average income distribution decreases by 1 percent, Zakat will decrease by 1,796 points. 


\section{Substance Analysis}

\section{a. Normality test}

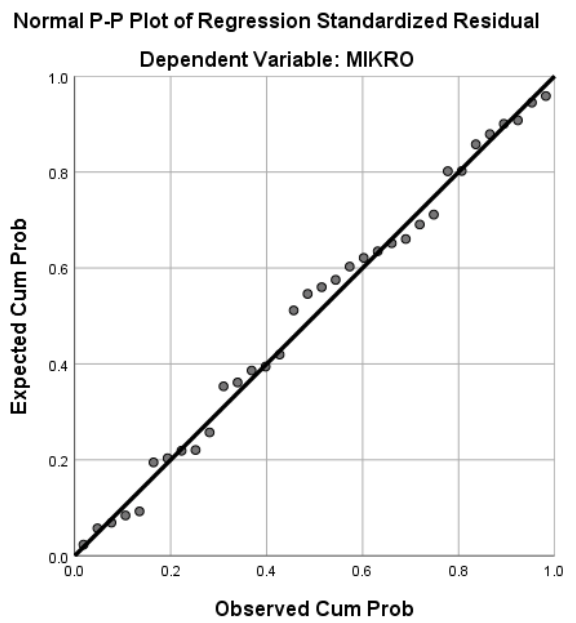

From the picture above, it can be seen that if the plotting data (dots) that describes the actual data follows the diagonal line, the be concluded that the regression model is normally distributed.

b. Multicollinearity Test

Table 3. Multicollinearity Test

\begin{tabular}{clllllll}
\hline Model & $\begin{array}{c}\text { Unstandardiz } \\
\text { ed } \\
\text { Coefficients }\end{array}$ & & $\begin{array}{l}\text { Standardized } \\
\text { Coefficients }\end{array}$ & t & Sig & & $\begin{array}{l}\text { Collinearity } \\
\text { Statistics }\end{array}$ \\
\hline B & $\begin{array}{l}\text { Std. } \\
\text { Error }\end{array}$ & Beta & & & tolerance & VIF \\
\hline 1(Constant) & -.193 & .402 & & -479 & .635 & & \\
HDI & .004 & .005 & .115 & .739 & .466 & .996 & 1,004 \\
GRDP & -012 & .010 & -191 & $-1,223$ & .231 & .991 & 1,009 \\
GINI & 1,796 & .574 & .489 & 3,132 & .004 & .986 & 1,014 \\
\hline a. Dependent Variable: MICRO & & & & & & \\
\hline
\end{tabular}

From the table above, it can be seen that the collinearity tolerance value for the variables X1 0.996, X2 0.991, X3 0.986, and the VIF values X1 1,004, X2 $1,009, \mathrm{X} 31,014$. If the tolerance value is $>0.100$ and the VIF value is $>10.00$, it can be concluded that there are no symptoms of Multicollinearity. 


\section{c. Scatterplots Heteroscedasticity Test}

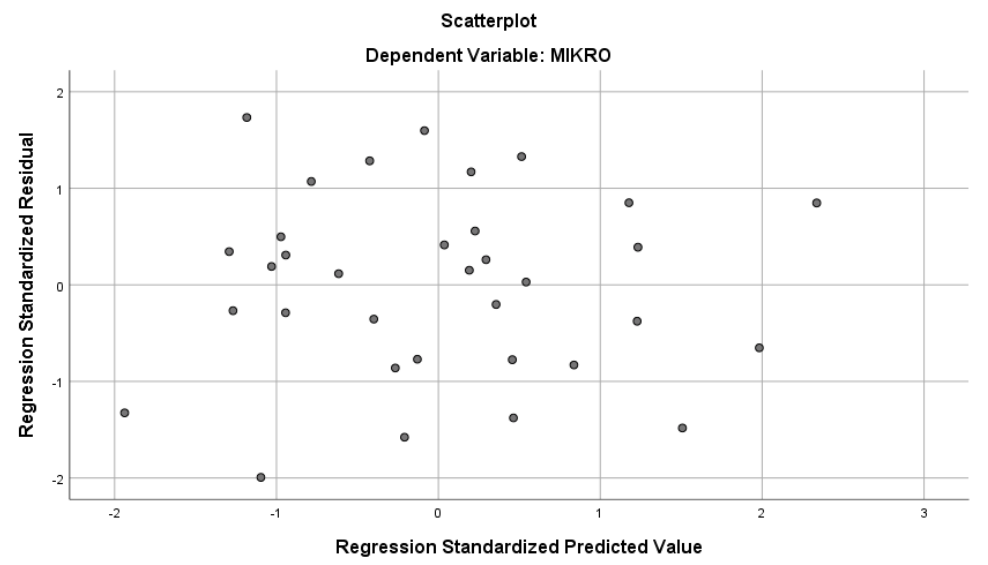

Based on the Heteroscedasticity test can be seen in the scatterplot graph above that shows the points are spreading irregularly or randomly, hence can be concluded that there is a variant error from the constant or homoscedastic equation in a regression.

\section{d. T test}

Table 4. $\mathrm{T}$ test

\begin{tabular}{cccccccc}
\hline Model & $\begin{array}{c}\text { Unstandardiz } \\
\text { ed } \\
\text { Coefficients }\end{array}$ & & $\begin{array}{l}\text { Standardized } \\
\text { Coefficients }\end{array}$ & t & Sig & & $\begin{array}{c}\text { Collinearity } \\
\text { Statistics }\end{array}$ \\
\hline B & $\begin{array}{l}\text { Std. } \\
\text { Error }\end{array}$ & Beta & & & tolerance & VIF \\
\hline H(Constant) & -.193 & .402 & & -479 & .635 & & \\
HDI & .004 & .005 & .115 & .739 & .466 & .996 & 1,004 \\
GRDP & -012 & .010 & -191 & $-1,223$ & .231 & .991 & 1,009 \\
GINI & 1,796 & .574 & .489 & 3,132 & .004 & .986 & 1,014 \\
\hline a. Dependent Variable: MICRO & & & & & &
\end{tabular}

Source: Primary data process, 2020

The table shows the $\mathrm{t}$ value of the variable $\mathrm{X} 1$ of $0.739, \mathrm{X} 2-1.223, \mathrm{X} 3$ of 3.132 , while the $t$ table value obtained was 2.042, meaning that if the value of $t$ count $>\mathrm{t}$ table, then the independent variable $(\mathrm{X})$ partially affects the dependent variable (Y) or other conclusions; X1 has no significant effect on $\mathrm{Y}, \mathrm{X} 2$ has no effect on $\mathrm{Y}$, and $\mathrm{X} 3$ has a significant positive effect on variable $\mathrm{Y}$. 
Table 4. F test

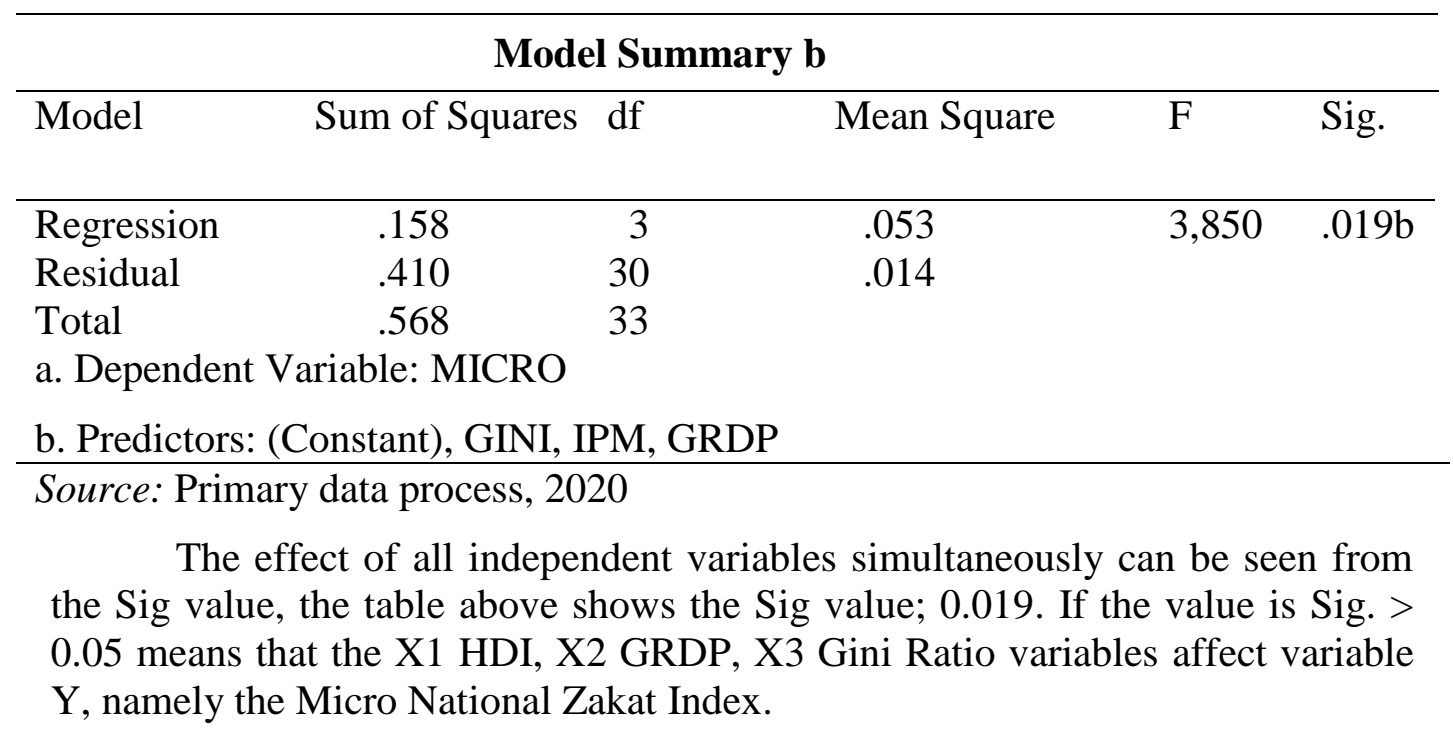

\section{f. R Square}

Table 5. R Square

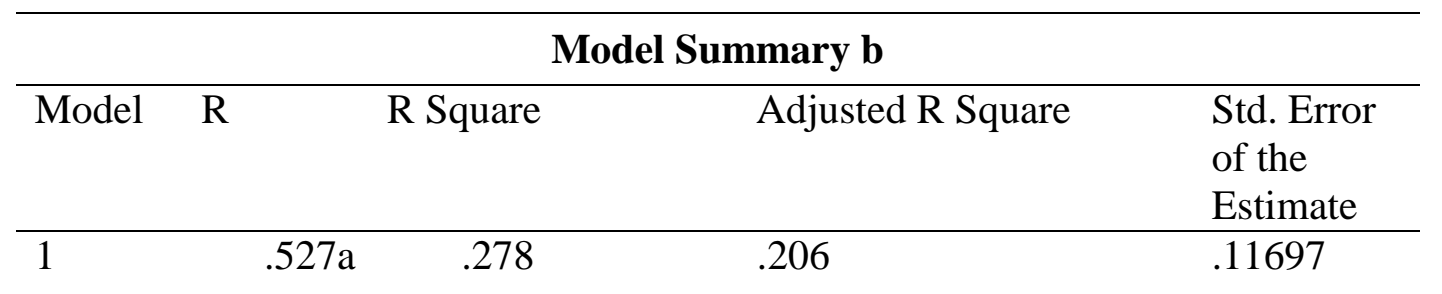

a. Predictors: (Constant), GINI, HDI, GRDP

b. Dependent Variable: MICRO

Source: Primary data process, 2020

Table 5 illustrates the coefficient determination result. The percentage of influence of variable $\mathrm{X}$ on variable $\mathrm{Y}$ observed from the value of $\mathrm{R}$ Square in the table above which is 0.278 . Then variable $\mathrm{X}$ simultaneously or partially influences $27.8 \%$ on variable $\mathrm{Y}$.

\section{g. Hypothesis Test}

Furthermore, hypothesis testing is carried out to determine the effect of the dependent variable on each independent variable. By referring to the level of significance in the data processing results below:

Table 6. Regression Result

\begin{tabular}{llc}
\hline Model & t & Sig. \\
\hline HDI & .739 & .466 \\
GRDP & $-1,223$ & .231 \\
Gini Ratio & 3,132 & .004 \\
\hline
\end{tabular}

Source: Primary data process, 2020 


\section{- HDI variable}

Decision: Accept $\mathrm{HO}$ because the P-value is $<5 \%$ with sig. (0.739)

Conclusion: The Human Achievement Index (HDI) variable has no significant effect on the Zakat variable.

- GRDP variable:

Decision: Accept H0 because the P-value is $<5 \%$ with sig $(0.231)$

Conclusion: The PDRB variable has no significant effect on the Zakat variable.

- Variable Gini ratio:

$\mathrm{H} 0: \beta 3=0$

$\mathrm{H} 1: \beta 3 \neq 0$

Decision: Reject $\mathrm{H} 0$ because the P-value $<5 \%$ with sig (0.004)

Conclusion: The poverty variable has a significant effect on the Zakat variable.

Based on the results of previous data processing, it shows that simultaneously the independent variables, namely the Human Development Index (IPM), Gross Regional Domestic Product (GRDP), and income distribution have a significant effect on the dependent variable of national zakat receipts. Although partially, not all independent variables affect the dependent variable.

The first independent variable tested is the HDI variable, which the results of the analysis show that the HDI has no significant effect on the zakat variable. The coefficient value of HDI on zakat receipts is negative -0.004 , which explained that if the average HDI increases, Zakat will decrease and vice versa if the average HDI decreases by 1 percent, Zakat will increase by -0.004 points. The results of this study contradict previous research conducted (Aksar, 2019) that HDI has a significant positive effect on zakat receipts in Indonesia. The results of different studies are observable from the type and amount of data used, including the year of research, in addition to the zakat variable in previous studies using total zakat collection data, including zakat fitrah and zakat maal. Meanwhile, in this study, researchers used the National Zakat Index; a performance measurement index based on macro and micro dimensions, with the aim that the resulting data can be more comprehensive.

As for the second variable, Gross Regional Domestic Product (GRDP), the test results show that GRDP has no significant effect on zakat receipts, with a probability value of $0.231>$ from alpha $0.05 \%$. It is in line with previous research by (Aksar, 2019) which states that GRDP has no significant effect on zakat receipts. In addition, opposite results were found on previous research by (Aziz, 2018) which showed that the GRDP variable had a significant outcome on zakat in East Kalimantan Province. Research with similar results by (Rahadiana, 2020) shows that GRDP as an economic benchmark has an effect on the development of the number of muzakki. Indirectly GRDP moderates between the increase in the number of muzakki and the amount of zakat receipts on a regional and national scale.

While the last independent variable, namely Income Distribution using the Gini Ratio index, has a significant positive effect on the zakat variable, with a positive coefficient value of 1.796, which means that the Gini Ratio average has the same effect as Zakah. In concept: income distribution is characterized by a 
ratio between $0-1$. The number 0 indicates perfect equality and the number 1 indicates the occurrence of perfect inequality. So if the average Gini Ratio increases, the Zakat will increase, and if the average income distribution decreases by 1 percent, Zakat will also decrease by 1,796 points. The results of this study are supported with other research by (Rakhmania, 2018) that partially, income variables have a significant positive effect on the interest of the people of Malang City in issuing their zakat. Specifically, the higher the public income, the greater the attentiveness in distributing zakat in terms of nishab of the treasure. Previous research by (Aksar, 2019) revealed a similar result, a factor of the number of wages received by the public in the Provincial Minimum Wage or muzakki income has a significant effect on motivation to pay zakat.

\section{CONCLUSION}

Based on the results and analysis achieved in this study, it can be concluded there is a direct relationship to the Gini ratio variable, which has a significant positive effect on Zakat with the greatest coefficient value of 3,132 points or $313.2 \%$. The other two variables, namely, HDI and GRDP have a subtle influence on Zakat. Overall, all independent variables have an effect of $27.8 \%$ on the dependent variable.

In short, the suggestion given from the conclusion of this study is clearly to improve the quality of Indonesian human resources, especially in rural and peripheral areas in Indonesia, seeing more cases of poverty that occur in rural areas. Qualified human resources with the skills needed in the world of work will definitely affect the quality of work and increase the income of each individual and possibly create new jobs to reduce unemployment.

Increased public income and good education to all levels of society regarding the importance of paying zakat, which includes an in-depth understanding of the benefits and positive impacts of the payment, gradually people begin to spend part of their income to pay zakat which has only been allocating for consumption. In addition, the transparency of the National Zakat Agency urged to generate a sense of trust in each community to distribute their zakat through Baznas.

\section{REFERENCES}

Aksar, N. A. (2019, Oktober). Pengaruh variabel Ekonomi Makro Dan Mikro Terhadap Jumlah Penerimaan Zakat Di Indoensia. Yogyakarta.

Analia Lumban Gaol, K. H. (2016). Pengaruh Kualitas Produk Terhadap Tingkat Kepuasan Konsumen Dan Loyalitas Konsumen. Jurnal Administrasi Bisnis (JAB) Vol. 38 No.1 September, 128.

Ashari, M. (2019, May 16). Potensi Zakat di Indonesia belum dimaksimalkan. Jakarta, Jakarta, Inodonesia.

at-Thabrani, I. (2012). Al Mu'jam Al Awsat Li At Thabrani. Libanon: DKI, Beirut.

Aziz, R. R. (2018). Pengaruh produk domesik regional bruto (sektor primer, sekunder, dan tersier) terhadap penerimaan zakat dan kemiskinan. Jurnal Ilmu Ekonomi Mulawarman. 
Badruddin, E. A. (2019). The Influence of Zakat on Economic Growth and Welfare Society in Indonesia. IJBE (Integrated Journal of Business and Economics, 65.

Beik, I. S. (2009). Analisis Peran Zakat dalam Mengurangi Kemiskinan: Studi Kasus Dompet Dhuafa. Jurnal Pemikiran dan Gagasan, 2.

Bisri, H. W. (2018). Analisis Pengaruh Faktor Bauran Pemasaran Jasa Terhadap kepuasan Nasabah (Studi Kasus BNI Syari'ah Kantor Cabang Cinere). Jurnal Moneter, Vol. V No.1 April, 65.

Clarashinta Canggih, K. F. (2017). Potensi Dan Realisasi Dana Zakat Indonesia. al-Uqud: Journal of Islamic Economics, 16.

Dewi Azizah Meydiasari, P. A. (2017, November). Analisis Pengaruh Distribusi Pendapatan, Tingkat Penganggura Dan Pengeluaran Pemerintah Sektor Pendidikan Terhadap IPM Di Indonesia. Jurnal Pendidikan Ekonomi Manajemen Dan Keuangan,, 01 No. 02, 118.

Fauzia, M. (2020, 1 15). Turun Tipis, Jumlah Orang Miskin di Indonesia Capai 24,79 Juta. Jakarta, Jakarta, Indonesia.

Himawan Yudistira Dama, a. L. (2016). Pengaruh Produk Domestik Regional Bruto (PDRB) Terhadap Tingkat Kemiskinan Di Kota Manado (Tahun 2005- 2016). Jurnal Berkala Ilmiah Efisiensi, 553.

I.K.Balyanda AKMAL, M. A. (2020). Does Zakat Matter For Human Development? An Empirical Evidence From Indonesia. Regional Science Inquiry, XII(2), 196.

Irvana Arofah, S. R. (2019). Analisis Jalur Untuk Pengaruh Angka Harapan Hidup, Harapan Lama Sekolah, Rata- Rata Lama Sekolah Terhadap Indeks Pembangunan Manusia Melalui Pengeluaran Rill Per Kapita Di Provinsi Nusa Tenggara Timur. Jurnal Saintika Unpam Vol.2, No.1, 81.

Juliarini, A. (2018). Kinerja Pendapatan Daerah Terhadap Indeks Pembangunan Manusia Studi Kasus Provinsi Di Pulau Jawa. Yogyakarta: Simposium Nasional Keuangan Negara SNKN.

Kasri, R. A. (2016). Effectiveness of Zakah Targeting In Alleviating Poverty In Indonesia. Al- Iqtishad: Jurnal Ilmu Ekonomi Syariah (Journal of Islamic Economics), 8(2), 169.

Kurniawan, T. Y. (2017, Agustus 08). wartaekonomi. Retrieved April 05, 2020, from wartaekonomi Web site: http://www.wartaekonomi.co id

Latuconsina, Z. M. (2017). Analisis Faktor- Faktor yang Mempengaruhi Indeks Pembangunan Manusia Kabupaten Malang Berbasis Pendekatan Perwilayahan dan Regresi Panel. Journal of Regional and Rural Development Planning, 1 No.2, 204.

Muhson, A. (n.d.). Teknik Analisis Kuantitatif. Retrieved April 4, 2020, from staffnew.uny Web site: htttp://www.staffnew.uny.ac.id

Nasional, P. K.-B. (2019). Indeks Zakat Nasional 2019 Wilayah III: Sulawesi. Jakarta: Pusat Kajian Strategis- Badan Amil Zakat Nasional (Puskas BAZNAS).

Programme, U. N. (2019). Human Develompent Reports. United Nations Development Programme.

Putera, A. D. (2018, Mei 26). ekonomi.kompas. Retrieved April 4, 2020, from ekonomi .kompas: http://www.ekonomi.kompas.com 
Rahadiana, S. D. (2020). Muzakki Potential's Role in Alleviating Poverty (Case Study of Aceh). IJIEF: International Journal of Islamic Economics and Finance, 3(1), 108.

Rakhmania, N. A. (2018). Pengaruh Pendapatan, Religiusitas, Kepercayaan, Dan Pengetahuan Terhadap Minat Muzakki Mengeluarkan Zakat Melalui Lembaga Amil Zakat Di kota Malang . Jurnal Ilmu Ekonomi fakultas Ekonomi Dan Bisnis Universitas Brawijaya, 12.

Saparini, H. (2020). Mengelola Orang Miskin Indonesia 5 Tahun Ke Depan. Indonesia Poverty Outlook 2020 (p. 3). Jakarta: Institute For Demographic and Poverty Studies (IDEAS).

Selatan, B. I.-B. (2019). Provinsi Sulawesi Selatan Dalam Angka. Makassar: BPS Provinsi Sulawesi Selatan.

Sobirin, N. H. (2016). Konsep Dan Teori Distribusi Pendapatan Dan Pemerataan pembangunan. Kudus: Universitas Muria Kudus.

Suprayitno, E. (2018). Zakat and SDG's: The Impact of Zakat on Economic Growth, Consumption and Investment in Malaysia. Advances in Economic, Business and Management Research, 101, 202.

Umaruddin Usman, E. B. (2018, April). Pengaruh Produk Domestik Regional Bruto, Investasi Industri Kecil Dan Jumlah Penduduk Terhadap Kemiskinan Kota Lhoksumawe (Studi Kasus Tahun 2006-2016). Jurnal Ekonomi Regional Unimal, 01 Nomor 01, 24-25.

UNDP. (2019). Human Development Report 2019 Beyond income, beyond averages, beyond today: Inequalities in human development in the 21 st century. USA: AGS, RR Donnelley Company.

Varlitya, C. R. (2017). Analisis Zakat Sebagai Pendapatan Asli Daerah Terhadap Indeks Pembangunan Manusia: Pendekatan Data Panel (Studi Kasus 12 Kabupaten/ Kota Provinsi Aceh). Jurnal Ekonomi Dan Kebijakan Publik Indonesia, 197. 